\title{
Impact of Accelerated Depreciation of Fixed Assets Policy on Corporate Financing Behavior-Based on DID, the Empirical Analysis of the Model
}

\author{
Danfeng Liao \\ School of Economics, Jinan University, Guangzhou, China \\ Email: jdjndx@163.com
}

Received 2 August 2016; accepted 22 August 2016; published 25 August 2016

Copyright (C) 2016 by author and Scientific Research Publishing Inc.

This work is licensed under the Creative Commons Attribution International License (CC BY). http://creativecommons.org/licenses/by/4.0/

(c) (i) Open Access

\begin{abstract}
For the manufacturing industry transformation and upgrading, the policy implementation of accelerated depreciation of fixed assets has an important influence. Through the choice of Listed Companies in Shanghai and Shenzhen financial data, we use the difference-in-difference model to verify the hypothesis. From the micro level of enterprises, we analyze how the fixed assets accelerated depreciation policy influences the corporate financing behavior. The study finds that the financing behavior is significantly influenced by the policy, and can effectively stimulate "cash flow" of enterprises and reduce the proportion of debt financing. And it is also conducive for the manufacturing industry to reduce the cost of capital and optimize the industrial structure. This paper supports the implementation of the policy, and provides a basis for the tax reform of depreciation policy.
\end{abstract}

\section{Keywords}

Accelerated Depreciation, Financing, Difference-in-Difference, Manufacturing Industry

\section{Introduction}

At present, the "new normal" economic growth is slowing, upgrading of the industrial structure should be constant. For this, on October 20, 2014, the Ministry of Finance and the State Administration of Taxation jointly issued the Notice to perfect the accelerated depreciation of fixed assets of enterprise income tax policy (Finance and Taxation [2014] No.75), to further improve the accelerated depreciation of fixed assets to clearly define the 
corporate income tax policy issues, as shown in Table 1 [1] [2]. The accelerated depreciation of fixed assets policy can not only alleviate the pressure of the enterprise funds, promote transformation and upgrade of enterprises, the government can also provide it to enterprise as a "preferential tax policy", namely accelerated depreciation of fixed assets to achieve the effect of deferred tax, the increased current of the enterprise can make use of the tax shield effect [3]. And De Angelo and Masulis (1980) think there is strong substitution between nondebt tax shields and the debt tax shield. Under the same condition, the enterprise can make use of depreciation of fixed assets and amortization of intangible assets, such as loss deduction of non-debt tax shields to achieve the effect of tax cuts and realize the tax revenue, rather than just rely on debt. In this way, after the policy accelerated depreciation of fixed assets, enterprises can use the increased non-debt tax shields and have less borrowing. Then, on one hand it can realize the tax revenue and on the other hand, it can also avoid the debt risk of bankruptcy.

In recent years, manufacturing industry faces a serious dilemma: 1) Labor costs rise. In recent ten years, the average manufacturing wage rose by an annual rate of $14 \%$, and appeared accelerating trend since 2006, more than the overall average wages. From 2002 to 2011, the average manufacturing wage increased by 3.3 times. But wage costs have risen in China, in 2010 and 2011 migrant workers' wage is as high as $19.3 \%$ and 21.2\%. 2) Shortage of capital investment. At present, small and medium-sized enterprises are facing increased costs, reduced export demand and difficulties of thin margins. Facing the current situation, some enterprises urgently need money to maintain production. Some need money for industrial upgrading, while fund shortage problem is not solved, it can only choose to shut down or collapse. Small and Medium-Sized Enterprises (SMEs) possess an important position and play an essential role in national economy, and when they seek the diversified, scaled and industrialized development of the company, they require a lot of money, but the reality is that financing is too difficult. Due to small scale SMEs, weak anti-risk ability, low credit rating, high regulatory costs, financial institutions, especially the state-owned commercial banks, are reluctant to lend money to small and medium-sized enterprises. 3) Excessive tax burden. China's fiscal revenue growth rate is much higher than economic growth. At the end of 2009 the World Bank issued a report, from 1995 to 2007, after removing the inflation, the government fiscal revenue increased by 5.7 times. "Forbes" magazine in 2005 published "global tax burden index", and China was listed as the second. In 2009-2011, macro tax burden level reached 31.5\%, 30.9\% and 32.2\%. 4) Excess capacity. The statistics show that China currently has a total of 24 industries, but 21 of them have the problem of excess production capacity. Textiles and garment industry and steel industry are the representative of the industry overcapacity. In steel industry, for example, according to the China steel association statistics, in late 2010, China's steel production capacity was 800 million tons, and in 2013 China produced 775 million tons.

Table 1. Accelerated depreciation of fixed assets related policy.

\begin{tabular}{|c|c|c|c|}
\hline Industry & Conditions & Policy & Instructions \\
\hline \multirow{2}{*}{$\begin{array}{l}\text { Six major industries } \\
\text { (biological pharmaceutical manufacturing, } \\
\text { special equipment manufacturing, railway, } \\
\text { shipbuilding, aerospace and other } \\
\text { transportation equipment manufacturing, } \\
\text { computers, communications and other } \\
\text { electronic equipment manufacturing, } \\
\text { instrument manufacturing, information } \\
\text { transmission, software and information } \\
\text { technology services) }\end{array}$} & \multirow[t]{2}{*}{$\begin{array}{l}\text { On January 1, } 2014 \text { after } \\
\text { the purchase of fixed } \\
\text { assets } \\
\text { (including building) }\end{array}$} & Shorten the useful life & $\begin{array}{l}\text { No less than } 60 \% \text { of the } \\
\text { enterprise income tax law } \\
\text { depreciation fixed number } \\
\text { of year }\end{array}$ \\
\hline & & Accelerated depreciation & $\begin{array}{l}\text { Double declining balance } \\
\text { method or sum of method }\end{array}$ \\
\hline \multirow[t]{2}{*}{ All industries } & \multirow[t]{2}{*}{$\begin{array}{l}\text { After January 1, } 2014 \text { to } \\
\text { buy the special instruments } \\
\text { and equipment for research } \\
\text { and development activities }\end{array}$} & $\begin{array}{l}\text { Unit value } \leq 1 \text { million, } \\
\text { one-off deducted when } \\
\text { calculating the taxable } \\
\text { income amount }\end{array}$ & \multirow{2}{*}{$\begin{array}{l}\text { Six small profit-making } \\
\text { enterprise in the industry } \\
\text { of research and } \\
\text { development and } \\
\text { production and operation } \\
\text { of public instruments and } \\
\text { equipment, to perform } \\
\text { one-time pre-tax deduction }\end{array}$} \\
\hline & & $\begin{array}{l}\text { Unit value }>1 \text { million, } \\
\text { shorten the useful life or } \\
\text { accelerated depreciation }\end{array}$ & \\
\hline All industries & $\begin{array}{l}\text { Fixed assets held by the } \\
\text { enterprise }\end{array}$ & $\begin{array}{l}\text { Unit value }<5000 \text { yuan, } \\
\text { one-time deducted when } \\
\text { calculating the taxable } \\
\text { income amount }\end{array}$ & \\
\hline
\end{tabular}


of crude steel. Still, the association says the pace of growth will slow to $3 \%$ this year from $7.5 \%$ last year. Overcapacity in the steel industry is larger than we imagined and China has too much steel capacity. This is clear from the price movement of common steel products, such as hot rolled coil, which is down a fifth in local terms this year.

Theoretically, accelerated depreciation of fixed assets policy can unleash the massive amount of capital to promote the renewal and reform of the business equipment. For the traditional industries are just like cocoon into a butterfly, they have particular significance to promote transformation, upgrade traditional industries and enhance overall national strength and regional competitiveness.

\section{System Background and Theoretical Analysis}

Since 1979 the enterprise depreciation system in China is an important topic of the reform. In 1985 the State Council formally promulgated the republic depreciation of fixed assets. In 1986 the Ministry of Finance promulgated the regulations, implementing rules for the depreciation of fixed assets of enterprises, which constituted the straight line depreciation, classification of Chinese current extraction and dispersed using depreciation system. In the process of implementation, the country has orderly put many policies measure to give more preferential treatment to enterprises, such as allowing main machinery and equipment production line of depreciation of the fixed number of year by $30 \%$, and so on. Four methods of depreciation are widely used: Straight-line, Units of output, Double declining-balance and Sum of the yeas digits. The advantage of Straight line method is simple and clear, liable to be master, but its defect is that it doesn't consider use intensity and level of assets. Value of fixed assets management and objective management, the separation result of depreciation of fixed assets accounting is incomplete and its value is not real, leading to the depreciation accounting untrue, inaccurate, affecting the authenticity of the cost and profit accounting. At present, there are many defects such as low ratio, long term and linearity depreciation policy in our nation's tax law depreciation policy, which is not favorable with development of enterprise and nation macro-economy. Throughout the history of economic development in developed country, tax expenditure policy, including tax credit, accelerated depreciation, has been broadly applied on tax practice, such as the United States in 1954 in the tax law stipulated that all enterprises implemented "accelerated cost recovery system (ARCS)", namely the system of accelerated depreciation of fixed assets.

Accelerated depreciation of fixed assets in the section "tax saving" transmission mechanism is the result of "tax shield effect", and the generalized tax shield includes debt tax shield and non-debt tax shields. Research on the debt tax shield is the same: debt interest generally included in the financial expenses, by the calculation method of the total amount of profit in the profit statement, shows: operating profit = operating income - operating cost - business taxes and additional - sales - management fee - financial expenses - asset impairment loss \pm investment gains - profit and losses from fair value changes; Profit total $=$ operating profit + non-operating income - non-operating expenditures; Net profit $=$ profit - income tax expenses. It can be seen that after the debt interest is included in the financial expenses, corporate profits less means lower income tax revenue, which makes the tax effect of debt interest appear. The debt tax shield mainly lies in the depreciation of fixed assets, amortization of intangible assets, etc. From the angle of accounting, the depreciation of the enterprise is generally included in the management cost, or included in the manufacturing cost first, then transferred to the cost of production. According to the formula for calculation of the operating profit of depreciation calculation also reduces enterprise's operating profit, so that enterprises should pay for enterprise income tax reduction and tax revenue (Figure 1).

Depreciation of fixed assets by tax shield effect, in turn, affects the financing behavior of the enterprise. According to "balance theory": the value of the debt enterprise equals to no debt enterprise value and general tax shield effect, and then minus the bankruptcy cost. When the debt equals to the marginal revenue, marginal cost can achieve the optimal financing behavior.

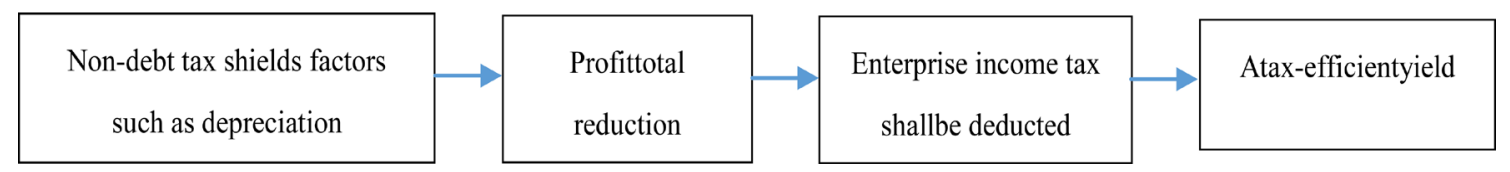

Figure 1. Non-debt tax shields mechanism. 
Further, accelerated depreciation of fixed assets can also reduce the enterprise cost of capital used, so that the marginal cost of investment declines to produce more cash flow. Therefore, the amount of investment per unit of enterprise can be saved $t * I(n), I(n)$ represents interest actually paid since $n$ year. Enterprise extract depreciation could also deduct the taxable income amount, it will reduce the real cost of enterprises to purchase assets. Tax depreciation deduction of savings is related to asset depreciation method and depreciation of fixed number of year. We use $D(n)$ to express the depreciation of the enterprise extraction and assume that the market interest rate $I$ is the discount rate for calculating the opportunity cost of capital, so the present value of the amount of tax savings in depreciation of unit assets is $\psi$ Formula can be used to indicate:

$$
\psi=\frac{t \times D(1)}{(1+i)}+\frac{t \times D(2)}{(1+i) 2}+\frac{t \times D(3)}{(1+i) 3}+\cdots+\frac{t \times D(n)}{(1+i) n} .
$$

Based on above analysis, accelerated depreciation of fixed assets in the non-debt tax shields has a tax-efficient effect, which should reduce corporate debt financing behavior. But it is not consistent with most of the literature. According to the United States on corporate tax law depreciation (Graham, 1996), covering loss is calculated by the relevant provisions of the marginal income tax rate of the enterprise. Through regression analysis, the author proved the depreciation tax shields effect; this factor in the tax on capital structure was not significant and the influence of marginal tax rates was almost not affected by depreciation or the investment tax credit [4]. In the study of capital structure decision theory, Wang B. (2004), who selected the Shanghai and Shenzhen a-share steel and non-ferrous metal plates in 1998-2002 data of listed companies as samples, through the multivariate linear regression analysis found that the accumulated depreciation of change and the operating cash flow ratio did not accord with western theories, and there were no significant variables in the equation. Possible explanations for the optimal sequence financing order of the west are not established in our country; the effective tax rate of listed companies which leads to lower tax revenue is not obvious, so the relation between depreciation and asset-liability ratio is not strong [5] [6].

Scott (1977) and Moore (1986) put forward non-debt tax shields, resulting from a fixed asset. Therefore, companies with more non-debt tax shields will also have a considerable number of guaranteed assets. Using these tangible assets to guarantee debt will reduce the risk of corporate debt financing. On the other hand, the less collateral assets business, the more difficult to get borrowing, leading to the depreciation and there is a positive correlation relationship between the capital structure [7]. Yao and Liu (2015), through the case example, summarize if the enterprise is in the income tax relief period, actual execution of the enterprise income tax rate may be very low or even zero. So, increasing as a result of accelerated depreciation is deducted in advance the low tax burden and even zero tax income. In this case, the tax effect of accelerated depreciation will not only because tax breaks are some or all offset, but also because tax reduction or exemption after depreciation reduces enterprise and achieves more profits, then enterprises pay enterprise income tax more [8].

Therefore, after the implementation of the policy of accelerated depreciation of fixed assets in 2014, the impact of the financing behavior of enterprises is still to be tested. Based on the double difference model and the classical theory, this paper puts forward the hypothesis: impact of policy of accelerated depreciation of fixed assets on the enterprise's financing behavior is significant, and negatively correlated to the capital structure, which can effectively reduce the debt ratio of corporate financing behavior.

\section{Policy of Accelerated Depreciation of Fixed Assets of Double Difference Model}

In exploring the macro policy made by the government to the economic and social part of the main body, while other subjects have little or no impact, we argue that the policy implementation is similar to "natural experiment" in the natural sciences. In the natural experiment, by comparing the experimental group and control group, the result can be distinguished. But in the economic society, for the policy effect assessment, it is difficult to strictly control and set the relevant influence factors caused by the deviation. In this paper, the implementation of accelerated depreciation policy for fixed assets can be seen as an exogenous event. The change of corporate financing behavior may also be factors such as macroeconomic fluctuations, exchange rates and interest rates. If only explores the accelerated depreciation of fixed assets policy before and after the financing behavior of related manufacturing differences, the policy impact on manufacturing financing behavior cannot be accurately judged. Even if the enterprise financing behavior changes, the existence of the policy and its correlation can also be proved, but the real reason may come from the enterprise scale and so on. In this paper, the method of accele- 
rating depreciation of fixed assets is regarded as a "quasi experiment". We introduce a double difference method (Method Differences-in-Differences, referred to as DID), stripping out the effect of the policy on corporate financing behavior of the net effect. We treat the affected by the policy of accelerated depreciation of fixed assets of the six major industries as treatment group, and other manufacturing industries as the control group (below referred to as "other industries"), which can effectively avoid the internal nature of the policy variables. At the same time, the "net effect" of the policy is integrated into the effective combination of the time dimension and the cross section dimension in the DID model. The net effect is shown in Figure 2, $t_{1}$ and $t_{2}$ can be seen as relevant policy of observation points, before and after the treatment group and before and after the policy change $\left(Y t_{2}-Y t_{1}\right)$. But it's not the real result of policy, in the absence of such a policy or for other reasons, such as the macroeconomic impact of the control group before and after the time difference $\left(Y c_{2}-Y c_{1}\right)$. Assuming treatment group and control group in the interference change trend is consistent, the size of the "net effect" of this policy is $\left(Y t_{2}-Y t_{1}\right)-\left(Y c_{2}-Y c_{1}\right)$.

Based on this, this paper uses asset-liability ratio $\left(\mathrm{LEV}_{i t}\right)$ as the explained variable, using "six major manufacturing industries $\left(\right.$ POLICY $\left._{i t}\right)$ " to indicate that it represents whether the enterprise's accelerated depreciation of fixed assets policy was implemented, the numerical value is equal to 1 on behalf of the six major manufacturing industries, the numerical value of 0 is on behalf of the six major industries in manufacturing enterprises, namely "other industries"; variable "policy implementation time (TIME $E_{i t}$ )" represents the time cross point, when the numerical value is equal to 1 for a year after the policy, the numerical value is equal to zero for the policy implementation of the previous year. In order to verify the effect of the policy, the interaction variable DID $_{i t}$ is set. When the POLICY it and TIME ${ }_{i t}$ at the same time are equal to 1 , the cross term is equal to 1 . Otherwise it is equal to 0 , and it is used to measure the net effect of the "new policy" on corporate finance ( $i$ is on behalf of the enterprise, $t$ represents the time). Thus, the sample can be divided into 4 groups: before the implementation of policy of manufacturing $\left(\right.$ POLICY $\left._{i t}=1, \mathrm{TIME}_{i t}=0\right)$, policy after implementation of manufacturing $\left(\mathrm{POLICY}_{i t}=\right.$ $\left.1, \operatorname{TIME}_{i t}=1\right)$, policy before the implementation of the control group $\left(\mathrm{POLICY}_{i t}=1, \mathrm{TIME}_{i t}=0\right)$, policy after implementation of the control group $\left(\mathrm{POLICY}_{i t}=0, \mathrm{TIME}_{i t}=1\right)$. The double difference model is:

$$
\mathrm{LEV}_{i t}=\beta_{0}+\beta_{1} \mathrm{POLICY}_{i t}+\delta_{1} \mathrm{TIME}_{i t}+\gamma_{0} \mathrm{DID}_{i t}+\varepsilon_{i t}
$$

Among them, $\beta_{1}$ is used to control the six manufacturing industry and the control group, $\delta_{1}$ is control time variable on the six manufacturing industries and the control group of the common impact, $\gamma_{0}$ is the key variable in this paper, which reflects the coefficient of policy effects.

In the control group, the POLICY ${ }_{i t}=0$ speeds up before and after the policy of fixed assets, the rates of assets and liabilities of manufacturing enterprises changes are:

$$
\left\{\begin{array}{l}
\beta_{0}+\varepsilon_{i t} ; \text { Before the policy, } \mathrm{TIME}_{i t}=0 ; \\
\beta_{0}+\delta_{1}+\varepsilon_{i t} ; \text { After the policy, } \mathrm{TIME}_{i t}=1
\end{array}\right.
$$

Accordingly, for the treatment group, because of the accelerated depreciation of fixed assets manufacturing enterprise asset-liability ratio before and after the policy changes, respectively:

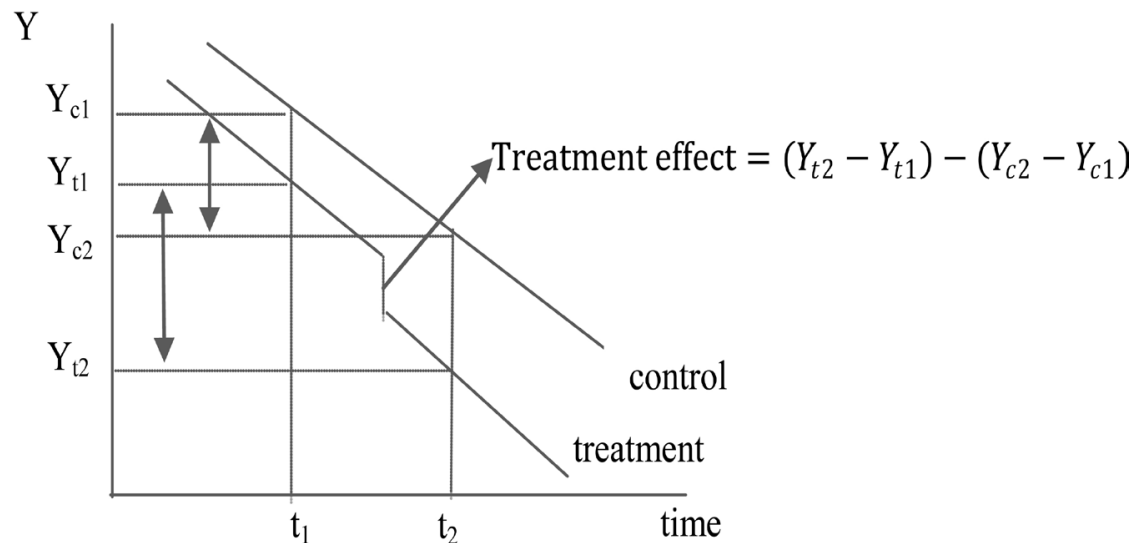

Figure 2. Double difference sketch "net effect". 


$$
\left\{\begin{array}{l}
\beta_{0}+\beta_{1}+\varepsilon_{i t} ; \text { Before the policy, } \operatorname{TIME}_{i t}=0 \\
\beta_{0}+\beta_{1}+\delta_{1}+\varepsilon_{i t} ; \text { After the policy, } \mathrm{TIME}_{i t}=1
\end{array}\right.
$$

As you can see, before and after the implementation of accelerated depreciation of fixed assets depreciation policy, the control group's asset liability ratio was $\delta_{1}$, while the asset liability ratio of the treatment group is $\delta_{1}+$ $\gamma_{0}$. So $\gamma_{0}$ is accelerated depreciation of fixed assets policy on six big industry "net effect" produced by the asset-liability ratio. When negative, it shows that the hypothesis is correct, and accelerated depreciation of fixed assets policy influences the financing behavior of manufacturing enterprises, and makes the enterprise to reduce debt.

\section{Empirical Analysis}

\subsection{Sample Selection}

Based on the policy before and after the implementation of accelerated depreciation of fixed assets in 2014 as study period, we choose the policy implementation of the previous year (2013) and after one year (2015) of Shanghai and Shenzhen a-share manufacturing listed companies as the sample data. We take six accelerated depreciation of the manufacturing industry for processing group, at the same time, other companies in the manufacturing are as the control group ${ }^{1}$. The related data are from CCER database and Wind database, etc. ${ }^{2}$. To ensure the robustness of the results, this paper introduced the related processing: 1) Remove within 3 years of newly listed companies, such companies do not have the continuity of data; 2) Remove the st companies, the companies are at risk of delisting and abnormal operating conditions; 3) Remove the missing data and financial indicators of extreme abnormal data.

\subsection{Variable Selection}

This article selects asset-liability ratio $\mathrm{LEV}_{i t}$ variables as corporate financing behavior change. At the same time, the industry policy variables $\left(\mathrm{POLICY}_{i t}\right)$, policy time variables $\left(\mathrm{TIME}_{i t}\right)$ and the interaction between the two (DID) are regarded as the independent variables. Then, we select the part of the control variables that affect the capital structure from the micro angle of corporate governance, corporate characteristics and so on, mainly such as the ownership concentration, the nature of the shareholders, the company size, non debt tax shields, liquidity and cash flow, profitability, asset structure, the actual tax burden. Relevant variables are defined as shown in Table 2. Therefore, the empirical model of this paper is as follows:

$$
\begin{aligned}
\mathrm{LEV}_{i t}= & \beta_{0}+\beta_{1} \mathrm{POLICY}_{i t}+\delta_{1} \mathrm{TIME}_{i t}+\gamma_{0} \mathrm{DID}_{i t}+\alpha_{1} \mathrm{TOP}_{i t}+\alpha_{12} \mathrm{TOP}{ }_{i t}+\alpha_{3} \mathrm{CIR}_{i t}+\alpha_{4} \mathrm{SIZE}_{i t} \\
& +\alpha_{5} \mathrm{NDTS}_{i t}+\alpha_{6} \mathrm{LIQ}_{i t}+\alpha_{7} \mathrm{CAS}_{i t}+\alpha_{8} \mathrm{ROA}_{i t}+\alpha_{9} \mathrm{ASS}_{i t}+\alpha_{10} \mathrm{TAX}_{i t}+\varepsilon_{i t}
\end{aligned}
$$

It should be stated that many factors affect the asset liability ratio of enterprises, but we focus only on the $\gamma_{0}$. In fact, it represents the actual impact of the policy.

\subsection{Descriptive Statistics}

To directly show the range of related variables and volatility in the whole sample, the descriptive statistics of the whole samples is presented in Table 3.

\footnotetext{
${ }^{1}$ Six major industries according to the national bureau of statistics of the national economy industry classification and code (GB/4754-2011): biological pharmaceutical manufacturing, special equipment manufacturing, Railway, shipbuilding, aerospace and other transportation equipment manufacturing, Computers, communications and other electronic equipment manufacturing, Instrument manufacturing, Information transmission, software and information technology services.

${ }^{2}$ CCER China's economic and financial database is one of the characteristic data service products offered by Xenophon, products include continuous updated capital market, money market and the national and regional macroeconomic data, has standardized database structure design, comprehensive data coverage, the strict quality control, the use of humanized and convenient interface.

Wind info is China's leading financial data, software and information service enterprise, the headquarters is located in Shanghai Lujiazui financial center. In the domestic market, Wind information of customers including more than $90 \%$ of Chinese securities companies, fund management companies, insurance companies, Banks and investment companies, financial companies; In the international market, has been approved by the China securities regulatory commission $75 \%$ of qualified foreign institutional investors (QFII) agency is Wind information of customers.
} 
Table 2. Relevant variables defined.

\begin{tabular}{|c|c|c|c|}
\hline & Variable name & $\begin{array}{l}\text { Variable } \\
\text { symbol }\end{array}$ & Variable definitions \\
\hline Dependent variable & Asset-liability ratio & LEV & Total debt/total assets \\
\hline \multirow{3}{*}{ Independent variables } & Policy variables & POLICY & $\begin{array}{c}\text { Industry dummy variables, when the six large industries value } 1 \text {, } \\
\text { otherwise the value } 0\end{array}$ \\
\hline & Time variable & TIME & $\begin{array}{c}\text { Dummy variables, year } 2015 \text { numerical value is equal to } 1 \text {, year } 2013 \\
\text { numerical value is equal to } 0\end{array}$ \\
\hline & Interactive variables & DID & $\begin{array}{l}\text { The dummy variable, belongs to the six major industry value and the } \\
\text { year of } 2015 \text {, the value is } 1 \text {, otherwise the value } 0\end{array}$ \\
\hline \multirow{10}{*}{ Control variables } & $\begin{array}{l}\text { The first big shareholder } \\
\text { shareholding }\end{array}$ & TOP1 & The first big shareholders holding at this/total equity \\
\hline & $\begin{array}{l}\text { The first ten big } \\
\text { shareholder's stake }\end{array}$ & TOP10 & The top 10 shareholders holding this/total equity \\
\hline & Free float & CIR & Circulation equity/total equity \\
\hline & Company size & SIZE & The natural logarithm of total assets \\
\hline & Non-debt tax shields & NDTS & Depreciation/total assets \\
\hline & Liquidity & LIQ & Current assets/current liabilities \\
\hline & Cash flow & CAS & Operating activities cash flow/total equity \\
\hline & Profitability & ROA & The total profit/total assets \\
\hline & Assets structure & ASS & Inventory/total assets \\
\hline & The actual tax burden & TAX & (Value-added tax and enterprise income tax)/profit \\
\hline
\end{tabular}

Table 3. Major variable description.

\begin{tabular}{ccccccc}
\hline & MEAN & Max & Min & Median & SD & N \\
\hline LEV & 0.38 & 0.98 & 0.02 & 0.37 & 0.19 & 2380 \\
POLICY & 0.35 & 1.00 & 0.00 & 0.00 & 0.48 & 2380 \\
TIME & 0.54 & 1.00 & 0.00 & 1.00 & 0.50 & 2380 \\
DID & 0.19 & 1.00 & 0.00 & 0.00 & 0.39 & 2380 \\
TOP1 & 0.34 & 0.90 & 0.03 & 0.33 & 0.15 & 2380 \\
TOP10 & 0.58 & 1.00 & 0.13 & 0.59 & 0.15 & 2380 \\
CIR & 0.77 & 1.00 & 0.05 & 0.84 & 0.24 & 2380 \\
SIZE & 21.92 & 26.96 & 17.39 & 21.77 & 1.15 & 2380 \\
NDTS & 0.02 & 0.57 & 0.00 & 0.02 & 0.02 & 2380 \\
LIQ & 2.79 & 54.37 & 0.18 & 1.82 & 3.47 & 2380 \\
CAS & 0.53 & 247.40 & -12.77 & 0.30 & 5.14 & 2380 \\
ROA & 0.07 & 11.01 & -0.59 & 0.05 & 0.32 & 2380 \\
ASS & 0.14 & 0.80 & 0.00 & 0.12 & 0.09 & 2380 \\
TAX & 0.17 & 1.00 & 0.00 & 0.11 & 0.17 & 2380 \\
\hline
\end{tabular}

In 2380 observations, we can see that manufacturing asset-liability ratio is on average of $38 \%$ of listed companies, in a reasonable range. The maximum is 0.98 and the minimum is 0.02 .We can see that the difference between the assets and liabilities rate of different enterprises is still relatively large.

\subsection{Empirical Analysis and Results}

1) Double Difference Method Suitability Test

When testing the experimental group and the control group, we still need to meet certain assumptions, that is, to remove the non policy effect; specifically, to ensure that the "fixed assets accelerated depreciation policy" on 
the manufacturing enterprise's selection process is random. At the same time, it required that the six major industries and other sectors had the same changing trend in asset liability ratio before the implementation of the policy.

Hypothesis 1: "accelerated depreciation of fixed assets policy" to the manufacturing enterprise is a random selection process. In the process of rapid development, the biggest industry of our economy-manufacturing industries has revealed many problems and difficulties into the development of the Lost. The manufacturing industry is the pillar industry of national economy. Its innovative upgrade is related to GDP growth and macroeconomic stability as a whole. As a result, the government chooses the policy of accelerated depreciation of fixed assets to solve the difficulties in manufacturing. The targeted support is not "chosen". And the implementation of the accelerated depreciation of fixed assets (e.g., the term structure, etc.) and corporate financing behavior has no correlation system. That is, the government is not based on the level of assets and liabilities of enterprises as the object of policy implementation; you can think the policy choice of enterprise is random.

Hypothesis 2: Six major industries and other sectors have the same changing trend in asset liability ratio before the implementation of the policy. Figure 3 shows capital structure situation of 2009-2013 about six big industries and other industry, it can be seen that before his policy of implementation of accelerated depreciation of fixed assets, although the asset-liability ratio is not equal, they have the same change trend. If we treat the difference between the two as a stable value, you can think control is appropriate. Further, this paper puts the assetliability ratio of first-order difference as explained variable, whereas the six major industries as virtual variables, and uses manufacturing data from 2009 to 2013 for fixed effects regression (Table 4). The results show that the first difference of the asset liability ratio of the six industry enterprises is statistically insignificant showing that the difference between the asset liability ratio of the six major industry enterprises and other manufacturing enterprises did not change significantly before the implementation of the policy.

2) Regression Analysis

A mix of OLS regression results is presented in Table 5. Under the premise of controlling corporate governance and the basic characteristics of the company, it is concluded that for interaction item DID the six major industries affected by the policy factor is 0.0102 , significant at $1 \%$ level. Despite the time variable is not through the test of significance, others conform to the relevant control variables with expectations, and have passed the test of significance, which shows that these variables have certain influence on the asset-liability ratio.

Interaction coefficient of $1.02 \%$ confirmed the hypothesis of this article. Compared with other industries, accelerated depreciation of fixed assets policy on six major industry financing behavior of the "net effect" is $1.02 \%$, namely the share proportion of financing liabilities significantly decreased by $1.02 \%$. Policy conduction effect reduces the outflows from enterprises, even in the short term the provision of depreciation of one-time will be included in the cost, and profit of the "virtual" causes the reduction of taxes so as to increase the current cash.

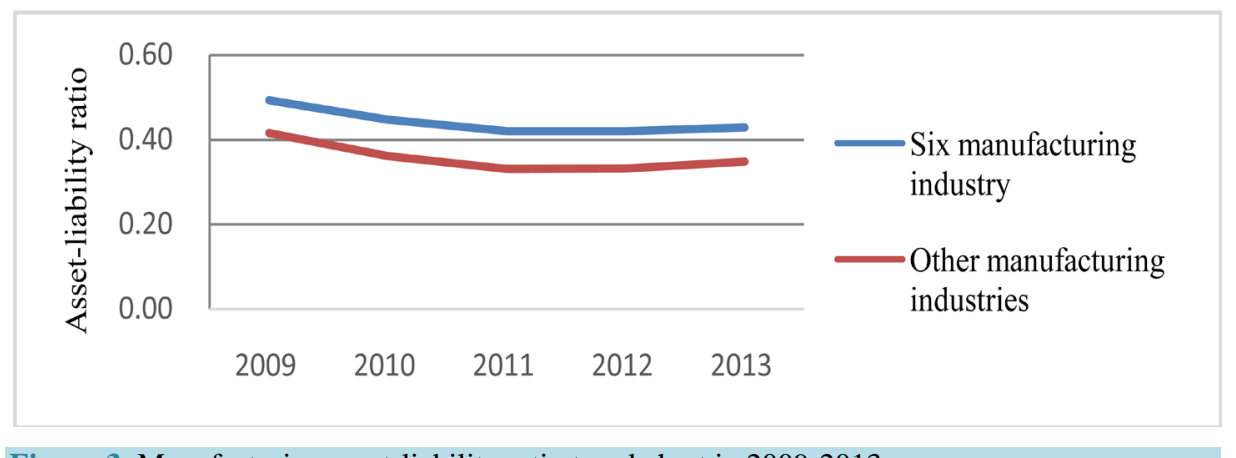

Figure 3. Manufacturing asset-liability ratio trend chart in 2009-2013.

Table 4. Reform asset-liability ratio similar between the two groups before returning.

\begin{tabular}{cc}
\hline & Asset-liability ratio difference \\
\hline Six manufacturing enterprise Virtual variables & 0.0036 \\
& $(2.45)$ \\
Constant term & 0.0015 \\
& $(0.97)$ \\
\hline
\end{tabular}


Table 5. The regression results of double difference model.

\begin{tabular}{|c|c|c|c|}
\hline Variable & Coefficient & T value & $P$ value \\
\hline POLICY & 0.0170 & $6.5103^{* * * *}$ & 0.0000 \\
\hline TIME & 0.0020 & 0.9015 & 0.3674 \\
\hline DID & -0.0102 & $-2.7862^{* * *}$ & 0.0054 \\
\hline TOP1 & -0.0742 & $-9.2226^{* * *}$ & 0.0000 \\
\hline TOP10 & -0.0834 & $-9.7612^{* * *}$ & 0.0000 \\
\hline CIR & 0.0207 & $4.7869^{* * * *}$ & 0.0000 \\
\hline SIZE & 0.0427 & $145.1948^{* * *}$ & 0.0000 \\
\hline NDTS & 0.3757 & $10.3506^{* * *}$ & 0.0000 \\
\hline LIQ & 0.0024 & $12.2383^{* * *}$ & 0.0000 \\
\hline CAS & -0.0145 & $-13.9847^{* * *}$ & 0.0000 \\
\hline ROA & 0.0151 & $5.2160^{* * * *}$ & 0.0000 \\
\hline ASS & 0.0533 & $5.4568^{* * *}$ & 0.0000 \\
\hline TAX & -0.0003 & $-2.0812^{* *}$ & 0.0375 \\
\hline
\end{tabular}

${ }^{*}$ in the table $10 \%$ level significant, ${ }^{* *}: 5 \%$ level significant, ${ }^{* * *}: 1 \%$ level significant, not labeled was not significant.

To further explain $1.02 \%$ of the "net effect", the policy of accelerated depreciation of fixed assets shall be also brought to the enterprise financing through financial channels. We use the double declining balance method, for example, an electronic equipment enterprises purchasing 60 million yuan in 2014, the salvage value at a rate of $1 \%$. It is expected to use five years by the straight-line method of depreciation, cost of capital rate is $10 \%$, and the income tax rate is $25 \%$. If according to the policy before 5 years depreciation, depreciation is equal to $60 \times$ $(1-1 \%) / 5=11.88$ million yuan, then annual depreciation tax effect is $11.88 \times 25 \%=2.97$ million, the time value of the present value is equal to $2.97 \times 3.79=11.2563$ million; If according to the rule of double declining balance depreciation, in the first year the amount of depreciation is $60 \times 40 \%=24$ million yuan, tax amount is $24 \times 25 \%=6$ million, convert present value is $6 \times 0.909=5.454$ million yuan. The same present value for the section in the second year of depreciation tax is equal to $(60-24) \times 40 \% \times 25 \% \times 0.862=3.1032$ million yuan, in the third year of depreciation tax-efficient present value is 1.6222 million yuan, in the fourth and fifth years equal to 1.1065 million yuan and 1.0044 million yuan respectively, present value of depreciation tax is 12.2903 million yuan. The difference between the two is equal to 1.034 million yuan, equivalent of an interest-free financing.

In fact, from the perspective of the development of tax burden of enterprise: although the accelerated depreciation of fixed assets policy did not change the overall tax burden of the enterprise, it was a tax "late prophase light weight". Apart from considering the time value of the money, for the moment in the plight of the urgent need for transformation of the manufacturing sector, after the completion of the upgrade optimization, the latter's tax burden ability will be enhanced. At the same time, enterprises are further increasing their investment on $R \& D$, which will enable enterprises to improve the ability of technological innovation, and thus be able to have more tax preferential treatment, the leverage of accelerated depreciation policy is to realize the directional development of capital-intensive industries and high-tech industry and complete the adjustment and transformation of social structure of the economy as a whole.

\section{Conclusion}

Though accelerated depreciation of fixed assets launched in 2014, the current research on this issue is relatively few, and also lack of empirical test in micro-enterprise level. This article selects the data of manufacturing listed companies as sample and uses the difference-in-difference model to analyze the policy's impact on its financing behavior from an enterprise micro level. The empirical results show that the enterprise's financing behavior is significantly influenced by the policy of accelerated depreciation of fixed assets, and can effectively activate the "cash flow" of the enterprise. The policy of "loan without fee" effect reduces the proportion of debt financing and the cost of capital on enterprises. The conclusion supported the policy of promoting the upgrade of tradi- 
tional manufacturing industry and developing emerging industry. At the same time, enterprises should seize the opportunity and give full attention to the accelerated depreciation policy, making use of "aid fund" and realizing the innovation and investment. For accelerated depreciation of fixed assets, of course, the policy of long-term effects and problems still needs to be further observed and discussed.

\section{References}

[1] The Ministry of Finance, State Administration of Taxation (2014) The Notice to Perfect the Policy of Enterprise Income Tax about Accelerated Depreciation of Fixed Assets.

[2] The State Administration of Taxation (2014) Tax Policy of Accelerated Depreciation of Fixed Assets.

[3] Zhao, M.N. (2015) Accelerated Depreciation of Fixed Assets for Enterprises under the New Policy. The Influence of the Friends of the Accounting, 6, 55-57.

[4] Graham, J.R. (1996) Debt and the Marginal Tax Rate. Journal of Financial Economics, 41, 41-74. http://dx.doi.org/10.1016/0304-405X(95)00857-B

[5] Xu, Y.X. and Lin, Z.W. (2011) VAT Reform and Decision on Enterprise's Fixed Assets Investment. Journal of Tax and Economy, 1, 90-97.

[6] Wang, B. (2004) Statistical Analysis of Capital Structure Influencing Factor of the Company, Based on the Contract Theory and Stakeholder Theory Thinking. University of Southwest of Finance and Economics, Chengdu.

[7] Scott Jr., J.H. (1997) Bankruptcy, Secured Debt and Optimal Capital Structure. Journal of Finance, 32, 1-19. http://dx.doi.org/10.1111/j.1540-6261.1977.tb03237.x

[8] Yao, H.Z. and Liu, Z.G. (2015) Accelerated Depreciation Is Not Necessarily Good for Enterprise. China Tax Report.

\section{Submit or recommend next manuscript to SCIRP and we will provide best service for you:}

Accepting pre-submission inquiries through Email, Facebook, LinkedIn, Twitter, etc.

A wide selection of journals (inclusive of 9 subjects, more than 200 journals)

Providing 24-hour high-quality service

User-friendly online submission system

Fair and swift peer-review system

Efficient typesetting and proofreading procedure

Display of the result of downloads and visits, as well as the number of cited articles

Maximum dissemination of your research work

Submit your manuscript at: http://papersubmission.scirp.org/ 